\title{
Affirmation of the Legal Status of Taxpayers in Montenegro
}

${ }^{*}$ Faculty of Law of the Mediterranean University in Podgorica

E-mail: srdja.bozovic@cbcg.me

\begin{abstract}
Public needs cannot be adequately funded without a clear and legally based affirmative legal status of taxpayers. The promotion and protection of their rights and regular fulfilment of tax obligations by taxpayers is the basis of fiscal and financial stability of the country and other public collectivities. It is essential for Montenegro to overcome the traditional gap between taxpayers and tax administration through their partnership. At the same time, we must not jeopardize the basic purpose of taxation - legal and timely payment of taxes. Simple and stable tax regulations and a non-discriminating and subtle approach to building tax discipline and development of tax morale should serve that purpose.
\end{abstract}

Key words: improvement and protection of taxpayer rights, fulfilment of tax obligations, functional legal status of taxpayers, country and taxpayer partnership

JEL classification: $\mathrm{H} 20, \mathrm{~K} 34$

\section{Introduction}

The universality of tax payment imposes the need to assume many different activities of entities in the tax-legal relationship chain. Government adopts tax laws through the legislative authority and the tax administration implements them.

The position of taxpayers in modern states (and this was also the case in premodern states) is regulated by tax law norms, tax laws, and fiscal legislation. This is not a unilateral status but the position based on public-legal relationship between taxpayers and tax authority in the process of securing funds to finance 
public needs. Therefore, this is a two-way relationship. Both state and taxpayers have the same public rights and public obligations (duties) ${ }^{1}$.

Taxpayers manifest their legal situation in the domain of property relations with the state, but also as participants in administrative-legal relations with the state.

The essence of property relations between taxpayers and state is tax liability, which consists in giving part of their economic strength from income and/or assets for tax claims of the state. This enables the exercising of the main purpose of taxation from an integral process of determining the tax liability to its collection. In order to accurately and efficiently, or in one word effectively, collect taxes, it is necessary that both parties in the administrative-legal relationship, the state and taxpayers, observe the rights and obligations imposed on them by the law.

The aim of this paper is not the state as a tax entity, but the taxpayers' legal position in the taxation process analysed in the context of promotion and strengthening of their rights and obligations. Although taxpayers' obligations are primary in the tax relation, this relation is largely relativized nowadays due to the inevitable correlation of these obligations with the corresponding taxpayers' rights. The answer to the concrete issue of taxpayers' legal position depends on assessing whether taxpayers' rights and obligations in a country are explicitly defined, whether they are in harmony or in conflict, or if there is a deviation from their implementation. Improving taxpayers' legal status may not be observed separately from fiscal authority`s behaviour that has a special role here.

\section{IMPROVING TAXPAYERS' TAX RIGHTS}

With their rights and obligations, taxpayers are the main support of a state's interest for adequate financing of public needs. As taxpaying entities, their role is decisive in the pursuing of the state functions. Voluntary tax payment is one of the priorities of fiscal authority's effective functioning in every country. This results from fiscal authority's accessible, understandable and timely services to taxpayers in meeting its tax obligations, primarily in assisting and informing (Organisation for Economic Co-operation and Development - OECD, 2007, p. 6). The problem of voluntary tax payment by taxpayers is not any kind of particular burden only to better organized countries with a high-level fiscal discipline

\footnotetext{
${ }^{1}$ Legal theory recognizes taxpayer's rights as individual general fundamental rights (equality before tax), and taxpayer's tax obligations as actual individual public duties.

See: Živanović, 1997, pp. 547 and 574
} 
and where tax culture is a part of normal behaviour. These countries, and nowadays a growing number of other countries as well, are committed to channelling available tax potential towards an effective collection of tax claims, aiming to voluntariness. To this end, as a necessary requirement of such practice, modern fiscal authorities have created the legal frameworks that properly define taxpayers' rights and protection.

Fiscal authority's rigidity towards taxpayers against the backdrop of new democratic developments causes irreconcilable antagonisms among them in practice, resulting in finding ways how to evade tax paying. Therefore, countries usually construct and improve their tax systems basing them on broader taxpayers' rights, guaranteeing their respect and protection from the abuse and autocracy of fiscal administration, which is the essence of reforms within the so-called New Public Management (Aberbach \& Christensen, 2007, p. 159). This results in higher and desirable level of partnership and trust, but also in relativizing relationship between the active tax entity (fiscal authority) and passive entities (taxpayers), to the extent possible. Regardless of the fact that taxpayers' obligations ultimately render the taxation purpose possible, nowadays they are increasingly harmonised with the volume and quality of taxation rights. A successful fiscal authority recognizes and seeks harmonious existence of taxpayers' rights and obligations and it is based on meeting a state's public interest to ensure a sufficient level of revenues to finance public needs on one hand, and private interests of taxpayers for equal taxation treatment and a stimulating and stable business and living environment, on the other hand.

Taxpayers' rights are a part of broader fundamental human rights and, as such, they are precisely defined in national legislation as a part of respecting these rights at the international level. It is important to note that tax rights are generally universal, they apply to all taxpayers, and they are available to everyone under equal terms.

\section{The right to be informed}

The taxpayers' right to be informed refers to the right to be accurately and timely informed about all issues in the process of tax calculation and collection. Tax authority should be accessible and open to taxpayers so that they would settle their obligations as simple and easy as possible. In this sense, taxpayers will be informed about their rights and obligations in the tax procedure, particularly about the current changes in taxes and the use of rights. Moreover, websites provide free information and access to legislation (laws, decrees, regulations, operational 
guideline) to be applied when calculating and collecting taxes. In addition, taxpayers receive answers to submitted questions on specific tax problems in writing, etc.

Advanced countries use different means and forms of informing their taxpayers such as information bulletins, manuals and guidelines on tax system functioning, charters on taxpayer rights and obligations, media writings, and brochures on tax calculation and collection, free telephone assistance lines, providing information and interpretations, and the like. All OECD member states publish general publications on their tax system functioning, as well as instructions on how to complete tax returns and the availability of tax incentives. Using special teaching materials for school, or even through educational programs, a large number of countries (France, New Zealand, Sweden, United Kingdom) bring tax issues, especially tax revenues spending, closer to taxpayers, while no more but few countries provide legal assistance and information to taxpayers through free telephone assistance line (Hrustić, 2006, p. 219-221).

\section{The Right to tax Confidentiality and Secrecy}

The right to confidentiality implies that the information that taxpayers disclose in the tax procedure, including documents and information and facts, as well as all other information and data kept or gained by the tax administration in the tax procedure may not be used for purposes other than for the purpose of the procedure and they may not be published. ${ }^{2}$ The obligation to keep tax secret refers to the tax authority officers, witnesses, expert witnesses, lawyers, notaries, and all other persons involved in the tax procedure.

Tax secret excludes the information and data:

1. for which the taxpayer states in a written form that they are not considered as tax secret;

2. that cannot be related to a particular taxpayer, and cannot be identified in any other manner;

3. pertaining to the existence of tax debt if the mortgage, or fiduciary transfer of property right used as security has been registered in the public books;

4. on registration of the taxpayer, FIN, name (firm) and principal place of business;

2 Most of countries arrange the possibility of sharing data and information in bilateral or multilateral agreements. 
5. value of immovable property;

6. data which the tax authority publishes quarterly on the list of tax debtors (Tax Administration Law, 2001, Article 16).

The purpose of this right is to protect taxpayers from potential abuse or misuse of data and information by all persons participating in the tax procedure. The abuse of tax information and disclosure of tax secret is subject to rigid penalties (criminal, misdemeanour, civil).

The right to keeping tax secret is limited to certain exceptions in many countries. Two exceptions are particularly notable. Information obtained for tax purposes may be made available to courts, public administration bodies, and social welfare entities only if they are protected under confidentiality measures applying to tax authorities. Similarly, disregarding that keeping bank secret is almost generally accepted in the relationship between bank and clients, tax administration is frequently legally empowered to obtain information from banks that may be useful in the tax procedure, subject to the obligation not to reveal such information to other entities.

\section{The Right to Privacy}

The right to privacy includes taxpayers' expectation that tax authorities will not unnecessarily interfere with their privacy. ${ }^{3}$ On the other hand, tax authority is obliged to respect taxpayers' right to privacy. In a narrow sense, this means that entry into, and search of, business and residential premises, and seizure of tax documents by tax authorities for the purpose of tax investigation is performed following precise procedures and in very specific situations. Tax systems recognise different modalities of exercising this right.

Some countries allow free access to taxpayers' business premises and apartments, even without prior notice (Australia, Austria, Canada, Japan). Some countries seek a condition of suspected tax evasion (Finland, Switzerland, the United Kingdom), while some countries that stipulated that entry into official and private quarters requires taxpayer's consent (France, USA, Spain). A search of taxpayers' business premises is usually subject to a court order. There are cases when apartments and offices may be searched without a court order (Ireland, Japan, New Zealand), while some countries allow the search only of business premises without a court order (Norway, Portugal). The practice of seizure of taxpayers'

\footnotetext{
3 For more details see: Bodiroga-Vukobrat \& Dulčić, 2005, p. 328-330.
} 
documents also differs. Some countries limit the seizure to cases of suspected tax evasion, others limit seizure on the account of suspected tax violations or tax offenses, and some require a court order and others can do it without it. ${ }^{4}$

Montenegro's taxation legislation lays down measures of the tax authority limiting the taxpayers' privacy and stipulating the procedure for their undertaking. During the inspection, if the tax authority determines that the taxation law or another tax proceeding is breached, it shall temporarily seize documentation, equipment and means of labour, prohibit disposing of funds in the account, prohibit conduct of activity, and the like ${ }^{5}$.

\section{The Right of Appeal}

The right of appeal is a general constitutional right of all taxpayers dissatisfied with the first instance decision of the tax authority. The Law stipulates that a taxpayer may lodge an appeal against a tax decision within 15 days as of the day of receiving the decision, and that an appeal may be filed against the decision on enforced collection within 3 days from the day of its submission (Law on Tax Administration, 2001 Articles 54 and 58).

Tax decision may be contested by an appeal, due to:

1. the violation of tax procedure rules if the decision was not issued by the actual competent tax authority, if the person supposed to participate in the tax proceeding as a party or interested person was not enabled to participate in the procedure or to present facts and circumstances crucial for decision making, or other violations defined by the provisions of the general administrative procedure;

2. incomplete or incorrectly established facts, e.g. if the amount of the tax liability was assessed based on the tax documentation that is not relevant due to the falsifying of data and facts on the amount of the tax base;

3. misapplication of substantial law, e.g. if elements strictly committed by systematic substantial tax legislation have been bypassed or "calculated" in assessing the tax base, applying tax rates, tax exemptions or deductions.

\footnotetext{
4 Interpreted Table 29 from: Hrustić, op.cit, P.222-224, source: J. Owens, 1990, “Taxpayers' Rights and Obligations", Paris: Intertax, OECD, no. 11/1990, p. 563-564.

${ }_{5}$ For an integral view, see: articles 87, 87a, and 88 of the Law on Tax Administration
} 
A second instance authority refuses an appeal when it determines that the procedure prior to the decision was executed correctly and in accordance with the law whereas the appeal is devoid of merit. It will also refuse an appeal when it finds that there were shortcomings in the first instance procedure that could not have had influence on issuing a decision on the administrative matter, and if it finds that first instance decision is based on the law, but for reasons other than the ones stated in the decision. In addition to refusing the appeal, a second instance authority will declare such a decision null and void completely or partially, and it may change it due to correctly determined reasons stipulated by general administrative procedure regulations (Law on General Administrative Procedure, 2003, Articles 235-239).

\section{The Right to Consistent Enforcement of Tax Regulations}

Strictly and consistently applied tax regulations are the basis for achieving the global "list" of taxpayers' tax rights. Although being a separate right, the right to consistent enforcement of tax regulations pervades and conditions other taxpayers' rights. In the narrowest sense, this right implies that the amount of tax is assessed correctly taking into account all substantial and procedural aspects of the legal act defined by relevant legal and other tax regulations. To be consistently applied, tax regulations should be clearly and accurately worded as to leave tax administration with as little dilemma and room for different interpretations as possible.

In practice, consistent application of tax regulations will be achieved when, in the tax procedure, taxpayer is correctly "assessed" the amount of tax due, no more no less. This means that, when specifying individual tax obligation, all elements that are quantitatively opted (determining the amount of the specific tax base, proper application of legally determined tax rate to the base, enabling taxpayers to use tax incentives provided by the law - tax exemptions and deductions, tax credits, deferment of tax liability, the right to tax refund, paying taxes in instalments) will be taken into account.

As its logical complement and an integral part, the subject right to consistent enforcement of tax regulations also points to the right to tax legislation stability and unacceptability of its retroactive application. Tax practice that would make tax regulations apply to taxpayers and situations that were not in force at a given time and frequent changes in the legal description of factual state directly endanger desired consistency of tax authority in the tax procedure. 


\section{Other Taxpayers' Rights}

The list of taxpayers' rights described in details above is by no means exhaustive. In addition, positive legislation in all modern tax systems recognises other taxpayers' rights that round off the integrity of taxpayers' legal position, the most important of which include:

1. the right of taxpayer and other persons in tax procedure to being treated with due respect by the tax authority;

2. the right to accessing data on assessment and collection of tax liability kept by the tax authority and to requesting changing incorrect or incomplete data;

3. the right to representation of personal interests before tax authorities, in person or via proxy;

4. the right to refund of excessively paid or inaccurately collected tax (i.e. tax overpayment) in the prescribed manner and within set deadlines (in Montenegro, the deadline is five working days following the receipt of the request)

5. the right to being present during the field audit;

6. the right to receiving explanatory documents passed during tax inspection and audit - minutes on field and office audit, decision on assessing tax adopted by the tax authority made on the basis of these controls, and decisions by which tax inspector orders measures in case of identified breach of the law, tax procedures or other tax legislation.

\section{REGULAR SETTLEMENT OF TAX LIABILITIES BY TAXPAYERS}

Payment of taxes by taxpayers is the ultimate purpose of taxation. To attain it successfully, a state stipulates explicit procedures that make up the taxation procedure. Taxpayers' obligations are a significant segment of this procedure. These are obligations to act, to refrain from acting, or to grant permissions due to lawful, proper and timely calculation and collection of taxes (Popović, 1997, p. 133).

Obligations to act are a set of actions of taxpayers and other passive tax entities that assist and facilitate the work of tax authority in assessing, collecting and controlling taxes (i.e. bookkeeping, preparing tax balances, filing tax returns and other documentation, submission of information and notifications, enabling the control of accuracy in assessing the amount of tax, compulsory opening of business accounts, tax payment, and the like). 
Obligations to refrain from acting represent taxpayers' behaviour to refrain from certain actions in order to facilitate the assessment and control of taxes, such as allowing the review of business books, the prohibition of registering property rights in cadastral books until paying the prescribed taxes, and the like. This is also the behaviour of taxpayers that facilitates the collection of taxes and other public revenues such as, for example, the compliance with the prohibition of disposing with funds from business account, the prohibition to pay salaries to employees without simultaneous paying taxes, etc.

In taxpayers' practice, the obligations to grant permission reflect in allowing the tax authority in certain legal situations to enter their personal and professional space that is "covered" with taxpayers' rights corpus. Thus, a taxpayer is obliged to allow a review of business books and other business documents and records, control of payments from business accounts, to be heard during the tax proceedings, and the like. The strength of taxpayers' legal position may be observed through close explanation of several such key obligations.

\section{The Obligation to keep Business Books and Records}

Taxpayers are obliged to keep business books and records in the prescribed manner and to keep them in accordance with law (Law on Tax Administration, 2001, Article 26). ${ }^{6}$ Business books mean the transaction journal, the general ledger and ancillary records (Law on Accounting and Auditing, 2005, Article 4). ${ }^{7}$ These are used for compiling financial statements - the statement of financial position and the statement of financial performance. Based on these financial statements, and primarily based on statement of financial performance, taxpayers compile tax balance, correcting certain positions with a view to determining legal entity's basis for corporate profit tax and/or basis for income tax from self-employment (taxable taxpayer's income) ${ }^{8}$.

The obligation of proper bookkeeping is based on four core principles:

6 Business books are unified records of inventories and changes in assets, equity and liabilities, and of revenues and expenses of legal entities and citizens engaged in self-employment.

7 Transaction journal is a primary book in which taxpayers enters business events in a chronological order, indicating the date of entry, document, and the amount following the doubleentry bookkeeping system. General ledger classifies business events according to the chart of accounts. Ancillary records are records of intangible investments, property, capital equipment, inventories, receivables, etc.

8 For more details see: Law on Corporate Profit Tax, 2001, Articles 7-24 and Law on Personal Income Tax, 2001, Articles 16-31. 
1. legality in keeping - implies their keeping based on authentic documents on specially established forms;

2. place of storage - usually in taxpayer's business premises or with a specialized entity;

3. efficiency in book entry - continuous recording of business events data;

4. fitness for inspection - quality of documents, contents of business books, and regularity of business changes ensures successful inspection of taxpayers (Anđelković, 1999, p. 126; Popović, op.cit, p. 141-142).

\section{The Obligation to Submit Tax Return}

Tax return is a formal document (a prescribed form) which, as a rule, taxpayers compile and submit to the tax authority and which contains taxpayers' registration data, as well as information legally relevant for determining facts and circumstances related to specific tax liability (general and specific part of the tax return).

Taxpayers submit the tax return to the tax authority of registration into the registry of taxpayers, directly or by mail, and it may submit it on a disc or in another form enabling computer data processing. Tax return is submitted for each type of taxes separately in the manner and within deadlines prescribed by tax laws (Law on Tax Administration, 2001, Article 36).

If the taxpayer has failed to submit the tax return within the prescribed deadline, the tax authority has the power to submit the tax return on behalf of the taxpayer within three days following the original due date. The tax authority also has the power to supplement an incomplete tax return as well as to correct incorrectly completed tax return immediately upon identifying omissions and mistakes in the submitted return.

Taxpayers and/or intermediary submits a tax return for withholding tax in the form of a report to the tax authority. Such a tax return may be collective or individual. A collective tax return contains information on calculated and paid withholding tax by one taxpayer or intermediary for all receivers of income, while an individual tax return refers to each individual receiver of income.

The aforesaid points to the evident benevolent interest of fiscal authorities to facilitate taxpayers' position, providing them with different manners of submitting tax returns. In addition, the legislator has envisaged the cases of "solidarity" power of the tax authority to act instead of "forgetful" taxpayers and/or taxpayers who inadequately perform their obligation to submit a tax return. 


\section{The Obligation to Pay Taxes on Time}

Tax payment within deadlines and in the manner prescribed by tax legislation, i.e. in timely and orderly manner, is the key taxpayers' obligation that completes the purpose and the objective of taxation. The act of paying taxes consists of physical handing over a sum of money owed for tax liability or the issuing of orders for funds transfer from the account of taxpayer or other statutory taxpayer to the payment account of tax creditor (the state, local authorities, etc.) (Popović, op.cit, p. 117; Law on Tax Administration, 2001, Articles 42a and 50).

When a taxpayer fails to pay the due tax liability, it is subject to enforced collection procedure. This shows the rigor and administrative consistency in the execution of regulations by the fiscal authorities. Enforced collection of taxes is not taxpayer's action but the surrogate for uncompleted action (Leitner, 1939, p. 214). In this case, in addition to settling the main tax debt, the taxpayer is obliged to pay default interest and costs of enforced collection.

However, the confirmation of structurally reinforced taxpayers' legal position in line with the tax authority's flexible conduct is expressed as the possibility of allowing a tax debtor to defer the payment of a tax and non-tax debt or to pay in instalments. At the tax debtor's request, under certain conditions, the Ministry of Finance may approve the payment of tax debt in no more than 12 monthly instalments, and it may postpone the entire or a part of tax for a period to up to six months (Decree on conditions for postponing the collection of tax and non-tax receivables, 2009, Articles 2-5).

\section{Other Taxpayer Obligations}

In addition to primary obligations, taxpayers have some special obligations. The following obligations have a high priority in the long list of such obligations:

1. the obligation to report facts necessary for assessing tax (e.g. establishment, changed address, or liquidation of a business entity, changing the municipality of business residence, permanent or temporary residence, etc.);

2. the obligation to provide data and cooperate with tax authorities in tax proceeding;

3. the obligation to participate in inspection audit, or in administrative audit, by invitation; 
4. the obligation to provide information regarding representation. (Ministarstvo finansija - Poreska uprava Crne Gore, 2015).

\section{FUNCTIONAL PROTECTION OF TAXPAYERS' TAX RIGHTS}

Disregarding that modern tax legislation has made significant developments in the field of expanding taxpayers' rights and their "getting closer" to the tax authority, there are obvious risk elements in practice that aggravate the implementation of taxpayers' key rights. Nowadays, a democratic and broad spectrum of taxpayers' rights bears risks for their protection reflected through the information explosion, unlimited exploitation of the public's need "to know", and uneven international cooperation in tax issues as well.

The taxpayers' position, including the "basket" of available rights, is provided and guaranteed at national and international level. This does not refer to any "specific" protection of taxpayers' rights, but to their participatory protection in the context of universal protection of citizens' individual public rights.

Ever since the French Declaration of the Rights of Man and of the Citizen of 1779 , national legal systems have incorporated many of these rights, while the Universal Declaration of Human Rights of the United Nations of 1948 represents a "global guarantee", in addition to other, individual citizens rights.

The Constitution of Montenegro notes that Montenegro guarantees and protects rights and liberties, which are inviolable and everyone is obliged to respect them. In addition, the Constitution guarantees equality before the law and equal protection of rights and freedoms. Civil equality is the foundation of the equality before tax principle, meaning that citizens exercise their tax liability according to their economic capabilities. This also means that taxpayers are protected from the tax authority's discriminatory behaviour in the tax procedure of assessing the amount of tax liability and its execution, control of taxpayers, but also from possible sanctioning of illegal actions.

The protection of taxpayers' legal position has internal (national) dimension, as well as external (international) aspect. Although national protection of taxpayers' rights may be said to be primary, this does not mean that it is devoid of superiority in many details and their international legal protection, particularly in recent time. 
Efficient, functional, and effective tax system does not and cannot exist unless it has resolved the issue of successful protection of taxpayers' rights in domestic legislation in its entirety and in all its basic elements. All modern states provide taxpayers with an effective remedy, which use protects their statutory status as entities which one part of economic capability enables the functioning of the state and other public collectivities. Remedies for the protection of taxpayers' endangered rights are placed in the administrative and judicial proceedings domain. Thus, the two-level administrative procedure, using the institute of appeal that may be applied to the largest number of decisions adopted by tax authorities, ensures a valid administrative and legal protection to taxpayers. Taxpayers' dissatisfaction with this form of protection against the tax authority can be "examined" in the judicial protection process. In several countries, taxpayers may prove the allegations of their rejection of the tax authority's decision before the regular court (the Administrative Court, in case of Montenegro) by filing a lawsuit in administrative dispute against the tax authority's final decision in the tax proceedings. Some countries "delegated" the judicial protection of taxpayers' rights to a special tax court, rather than seeking justice before the regular court (Arsić, 2000, p. 96) .

Taxpayers' status regarding the use of appeals in the two-level tax administrative proceedings and lawsuits in administrative disputes is questionable in a certain sense given that, in a large number of tax systems, such remedies do not delay the payment of taxes, i.e. they have no suspensive effect (OECD, 1990, p. 23). In this way, this complicates the taxpayers' financial position and shows prioritising of the state and its interests. In Montenegro, as well, the appeal against the tax decision does not delay its execution (Law on Tax Administration, in 2001, Article 54 $)^{10}$.

In addition to administrative and judicial protection, to protect their rights, taxpayers in most countries enjoy the possibility of engaging a particular institution as a professional control of administration - the Ombudsman. As a body "sensitive to the people", dealing with the general protection of citizens' rights from improper work of administration, it is used well for taxpayers' needs when their rights in proceedings before the tax authority are not exercised or when they are breached or misinterpreted. In fact, taxpayers in Montenegro may approach the

9 Special tax courts are atypical "bodies", usually appointed by national government and, depending on the country, consisting of tax experts, laymen, or mixed composition, tasked to assess the decision of the tax authority through an independent procedure.

${ }^{10}$ However, there are more OECD countries (two thirds) where the appeal stays the enforcement of the decision. 
Ombudsman when they consider that their rights have been violated by an act, action or inaction of the tax authority. The practice of some countries (the USA and Austria), with a special ombudsman institutionalized for tax issues, best confirms the importance of this form of protection of taxpayers' rights.

The use of taxpayers' remedies at the international level is not possible. Taxpayers are not entitled to the protection before the European Court of Human Rights since Article VI of the European Convention on Human Rights does not apply to tax disputes.

The right to taxpayers' protection at the international level can be expressed in three forms: 1 . the right of taxpayers to be informed on the requested information and their content; 2 . the right to proper participation of taxpayers in the process of information gathering; 3 . the right to verifying the legality and justification of sharing tax information by an independent body ${ }^{11}$.

Nevertheless, the protection of taxpayers' rights is also challenged in the part referring to the provision of international tax assistance between national tax authorities. Bilateral or multilateral agreements on mutual administrative assistance in tax issues, containing a number of institutes such as the sharing of data and information, carrying out host tax inspections abroad etc. are certainly of high importance in combating tax evasion and preventing criminal activities in this area. With a view to protecting taxpayers' rights, the reciprocity in their implementation should generally be a condition for this kind of cooperation. In cases of host tax audits, given that taxpayers are not contracting parties of international tax treaties, they may not expect to be provided with the protection of the right to privacy and confidentiality of information. Few countries have specified the legal obligation to inform taxpayers on submitting tax information to foreign tax and other authorities, while it is most common to perform tax inspection abroad at the taxpayer's request, yet never without the consent of the taxpayers subject to the tax inspection proceeding (Anđelković, 2008) ) $^{12}$.

\footnotetext{
${ }^{11}$ For more details, see: Seer \& Garet, 2011.

${ }^{12}$ Montenegro has not established the taxpayers' right to the previous notification that the tax authority will submit their tax records to foreign tax administrations, as it was done by the USA, Switzerland, and the Netherlands, for example.
} 


\section{Conclusion}

Building a taxpayers' functional legal position, based on providing a wider range of rights and simultaneously on determining numerous obligations, is the highest priority task of modern tax systems. Modern states tackle it by arranging the fiscal system so that taxpayers are made engaged entities in the taxation-legal relationship and not just mere passive agents of a state's taxation system. The taxation law corpus and the treatment of taxpayers' tax obligations should be established following the principles of easier and understandable acceptance and voluntary tax payment.

To that end, taxpayers' legal position should nowadays be observed in relation to the overall promotion and strengthening of an individual's subjectivity and rights, which is done by the integration into various international structures sharing the values of developed human rights. It is necessary that the deep gap between taxpayers and tax authority, which has been present for centuries and the measure of their relationship as such, where it was clear "who was in charge", is nowadays slowly transferring to a partnership relation. This getting closer results from the circumstances and countries' need to meet the increased and legitimate taxpayers' interests to consider their rights necessarily in the context of contributing to financing the growing volume of different general and common expenses. In fact, the responsibility of taxpayers, as persons who bear the entire burden of financing public expenditure, has to confront objectively to the inherited wide tax authority's powers in order to respect taxpayers' personality. Such orientation implies a new, primarily service oriented role of tax authorities who apply tax legislation whilst fully respecting each taxpayer as long as their actions are subordinated to the primary purpose of taxation - legal and timely settling of tax liability.

It is crucial that modern states formulate, ensure, and guarantee a wide range of tax rights available to all taxpayers. This is evidenced by the experience of developed countries which fiscal legislation established a wide list of tax rights, many of which have made an additional step by codifying these rights in special legal acts - charters and declarations, such as Canada, Great Britain, France, the United States. Montenegro followed this approach and the Ministry of Finance - Tax Administration adopted the Taxpayers' Charter in 2015. The Charter describes and explains in detail the taxpayers' rights so that they may familiarize with them in one place, while the tax authority legitimizes its interest in improving the taxpayers' legal position, offering its services in the implementation of their rights. 
Exercising of the most important taxpayers' obligation to pay taxes, and of all other obligations that are in this function (taxpayers' registration, filing tax returns, bookkeeping, etc.), will be better organized and with less resistance if applying the taxpayers' rights in a quality manner and creating favourable environment and the confidence between the state and taxpayers. The practice of fiscal authorities, which precisely and undoubtedly formulates acceptable, productive and sustainable fiscal policy objectives, strongly contributes to strengthening the taxpayers' legal position. Moreover, objective and fair sharing of tax burden specified in clear, simple, and stable tax regulations and an unselective and subtle approach to building tax discipline and development of tax ethics raises the level of understanding and accepting tax obligations. 


\section{References:}

1. Aberbach, J. D. \& Christensen T. (2007). The Challenges of Modernizing Tax Administration: Putting Customers First in Coercive Public Organizations. Public Policy and Administration. 22(2). SAGE Publication Ltd.

2. Anđelković M. (1999). Poresko pravo. Niš.

3. Anđelković M. (2008). Fundamentalna prava poreskih obveznika i njihova zaštita u savremenim informaciono-tehnološkim uslovima. Strani pravni život. br. 3/2008. p. 163-178.

4. Arsić M. (2000). Poreski obveznik i njegova prava - objektivnost i pravičnost. Ekonomski signali. jul/avgust 2000.

5. Bodiroga-Vukobrat N. \& Dulčić K. (2005). Zaštita osobnih podataka u europskome i hrvatskom pravu. Zbornik radova Pravog fakulteta u Splitu. str. 328-330.

6. Hrustić H. (2006). Javne finansije i poresko pravo. Beograd: Pravni fakultet Univerziteta Union i JP "Službeni glasnik". str. 219-221.

7. Leitner A. (1939). Uvod u studij poreznog prava. Zagreb: Vlastita naklada.

8. Ministarstvo finansija - Poreska uprava Crne Gore (2015). Povelja poreskih obveznika. Retrieved from

http://www.poreskauprava.gov.me/rubrike/Novosti_i_informacije_za_ poreske_obveznike/154885/POVELJA-PORESKIH-OBVEZNIKA-PRAVAI-OBAVEZE.html

9. Organisation for Economic Co-operation and Development - OECD (1990). Taxpayers' Rights and Obligations. Paris.

10. Organisation for Economic Co-operation and Development - OECD (2007). Improving Taxpayers Service Delivery: Channel Strategy Development.

Prepared by Forum on Tax Administration Services Sub-group, Approved by Committee on Fiscal Affairs. May 2007.

11. Popović D. (1997). Nauka o porezima i poresko pravo. Beograd: Savremena Administracija.

12. Seer R. \& Garet I. (2011), European and International Tax Cooperation: Legal Basis, Practice, Burden of Proof, Legal Protection and Requirements. Bulletin for International Taxation. Volume 65, Number 2. IBFD. p. 94-98.

13. Službeni list CG (2009). Uredba o uslovima za odlaganje naplate poreskih $i$ neporeskih potraživanja. Službeni list CG br. 67/09, 23/10 i 62/10.

14. Službeni list RCG (2001). Zakon o poreskoj administraciji. Službeni list RCG, br.65/01, 84/04, 29/05, Službeni list CG, br. 73/10, 20/11, 28/12, 8/15.

15. Službeni list RCG (2001). Zakon o porezu na dobit pravnih lica. Službeni list RCG, br. 65/01, 12/02, 8/04, Službeni list CG, br. 40/08, 86/09, 40/11, 14/12, $61 / 13$. 
16. Službeni list RCG (2001). Zakon o porezu na dohodak fizičkih lica. Službeni list RCG, br. 65/01, 37/04, 78/06, Službeni list CG, br. 86/09, 14/12, 06/13, $62 / 13$ i $60 / 14$.

17. Službeni list RCG (2003). Zakon o opštem upravnom postupku. Službeni list RCG, br. 60/03 i Službeni list CG, br. 32/11.

18. Službeni list RCG (2005). Zakon o računovodstvu i reviziji. Službeni list RCG, br.69/05, Službeni list CG, br. 80/08 i 32/11.

19. Živanović T. (1997). Sistem sintetičke pravne filozofije - sintetička filozofija prava I. Beograd: NIU Službeni list SRJ. 